\title{
A NEW UPPER SILURIAN CONODONT SPECIES FROM ESTONIA
}

\author{
Viive VIIRA
}

\begin{abstract}
Eesti Teaduste Akadeemia Geoloogia Instituut (Institute of Geology, Estonian Academy
\end{abstract} of Sciences), Estonia pst. 7, EE-0100 Tallinn, Eesti (Estonia)

Presented by D. Kaljo

Received April 6, 1993; accepted September 17, 1993

\begin{abstract}
A new conodont species Ozarkodina roopaensis sp. $\mathrm{n}$. is described from the Ludlow-age Roopa cliff of the Paadla Formation, corresponding to the uppermost part of the Gorstian Stage. The O. roopaensis conodont Zone represents part of the Ludlow nearshore zonation scale in the East Baltic. The new species of Ozarkodina is related to Ozarkodina confluens, but differs in $\mathrm{Pa}$ element having primitive transverse ridges on oral smooth surfaces of denticles. Characteristic is the distribution of white matter.
\end{abstract}

Key words: taxonomy, conodonts, Silurian, Estonia.

During the study of Silurian conodonts of Saaremaa, Estonia, the author's attention was attracted by big conodonts resembling Ozarkodina confluens, which were provisionally named Ozarkodina sp. S (Viira, 1982; Männik \& Viira, 1990). This paper presents a description of this new conodont species under the name of Ozarkodina roopaensis sp. $\mathrm{n}$. The type locality of the new species is the Roopa cliff on the west coast of Saaremaa Island (Fig. 1). The cliff, of about $1.5 \mathrm{~m}$ in height, represents a small bioherm, which is surrounded and underlain by brownish coarse skeletal limestone containing big ostracodes Herrmannina sp. (L. Sarv, pers. comm.). The bioherm is formed by the stromatoporoid Syringostromella borealis (Nicholson) and tabulates Thecia swindereniana (Goldfuss), Favosites pseudoforbesi Sokolov, and Subalveolites sp. (Қлааманн, 1970). The rocks of the Roopa cliff are supposed to belong to the Himmiste Beds of the Paadla Formation, which correspond to the uppermost part of the Ludlow Gorstian Stage (Клааманн, 1970; Kaljo, 1990). Besides Ozarkodina roopaensis sp. $\mathrm{n}$. the coarse skeletal limestone of the Roopa cliff has yielded also the conodonts Ozarkodina confluens cornidentatus Viira, O. excavata (Branson et Mehl), O. aff. snajdri crispa (Walliser), Oulodus siluricus (Branson et Mehl), Panderodus spp. (Pl. I). This conodont assemblage is also identified in the Karala and Kärla outcrops, and Ohesaare, Riksu, and Kolka borings. These localities are situated in the western part of Saaremaa, except Kolka, which is in northernmost Latvia.

Ozarkodina roopaensis $\mathrm{sp}$. n. has local biostratigraphic significance in the East Baltic Ludlow, where the corresponding conodont zonation was established already in 1982 (Viira, 1982). The Ozarkodina roopaensis Zone (=Ozarkodina sp. S Zone) represents a part of the nearshore zonation and corresponds to the Ozarkodina aff. snajdri Zone in the offshore 


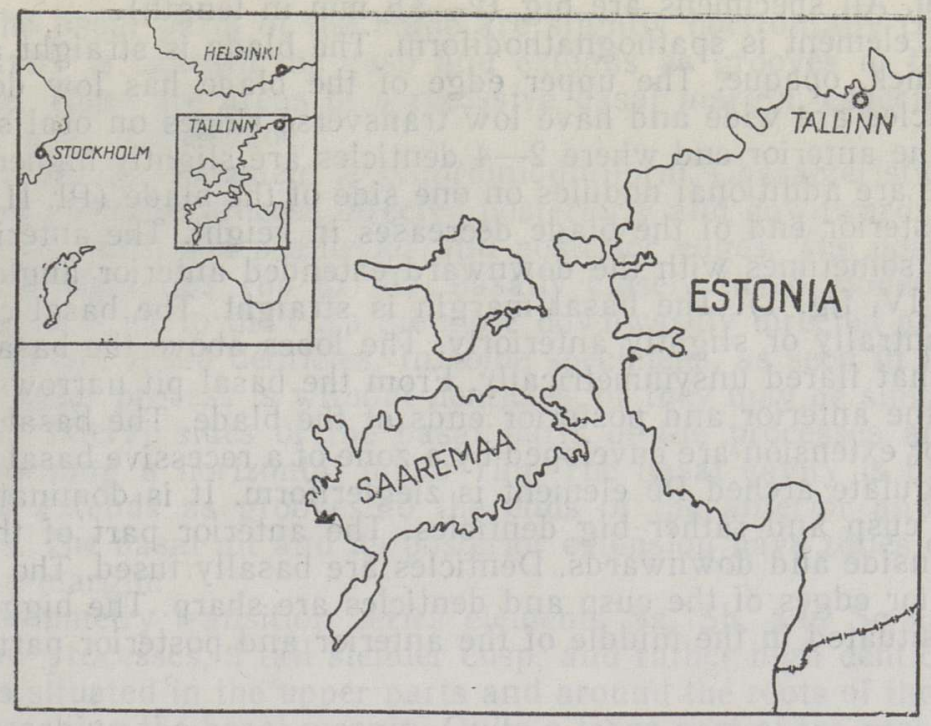

Fig. 1. Location of the Roopa cliff (triangle).

zonation (Männik \& Viira, 1990). Part of the O. roopaensis Zone may be correlated with the Polygnathoides siluricus Zone.

Specimens described in this work are housed at the Institute of Geology, Estonian Academy of Sciences (Catalogue Nos. Cn 1381-Cn 1435).

\section{SYSTEMATIC PALEONTOLOGY}

Phylum CHORDATA Bateson, 1886

Class CONODONTA Eichenberg, 1930, sensu Clark, 1981

Order OZARKODINIDA Dzik, 1976

Family SPATHOGNATHODONTIDAE Hass, 1959

Genus Ozarkodina Branson et Mehl, 1933

Type species. Ozarkodina typica Branson et Mehl, 1933

Ozarkodina roopaensis sp. $\mathrm{n}$.

Pl. II, figs. $1-9$; Pl. III, figs. $1-8$; Pl. IV, figs. $1-8$;

Fig. $2 A-O$

1982 Ozarkodina sp. S - Viira, p. 81

1990 «Ozarkodina» sp. S - Männik \& Viira, p. 88-89

Derivation of name. After Roopa cliff, the type locality of the species.

Holotype. Specimen Cn 1381, P1. II, fig. 1, from Roopa cliff.

Type stratum. Ludlow Series, Paadla Formation, Himmiste Beds.

Diagnosis. $\mathrm{Pa}$ element carminate with fused denticles and primitive transverse ridges on oral surfaces of denticles. $\mathrm{Pb}$ element angulate, arched, with anterior blade curved inwardly. Denticles of $M$ and $S$ elements big and long, compressed laterally. Distribution of white matter is around the axes of denticles. 
Description. All specimens are big (2-3.5 $\mathrm{mm}$ in length).

The $\mathrm{Pa}$ element is spathognathodiform. The blade is straight and moderately thick, opaque. The upper edge of the blade has low denticulation. Denticles are wide and have low transverse ridges on oral surfaces, except at the anterior end where 2-4 denticles are slightly higher. Sometimes there are additional nodules on one side of the blade (Pl. II, figs. 4, $5)$. The posterior end of the blade decreases in height. The anterior edge is upright, sometimes with the downward extended anterior angle (Pl. I, fig. 2; Pl. IV, fig. 1). The basal margin is straight. The basal cavity is situated centrally or slightly anteriorly. The lobes above the basal cavity are somewhat flared unsymmetrically. From the basal pit narrow grooves extend to the anterior and posterior ends of the blade. The basal pit and its posterior extension are enveloped by a zone of a recessive basal margin.

The angulate arched $\mathrm{Pb}$ element is ziegleriform. It is dominated by a prominent cusp and rather big denticles. The anterior part of the blade is curved inside and downwards. Denticles are basally fused. The anterior and posterior edges of the cusp and denticles are sharp. The biggest denticles are situated in the middle of the anterior and posterior parts of the

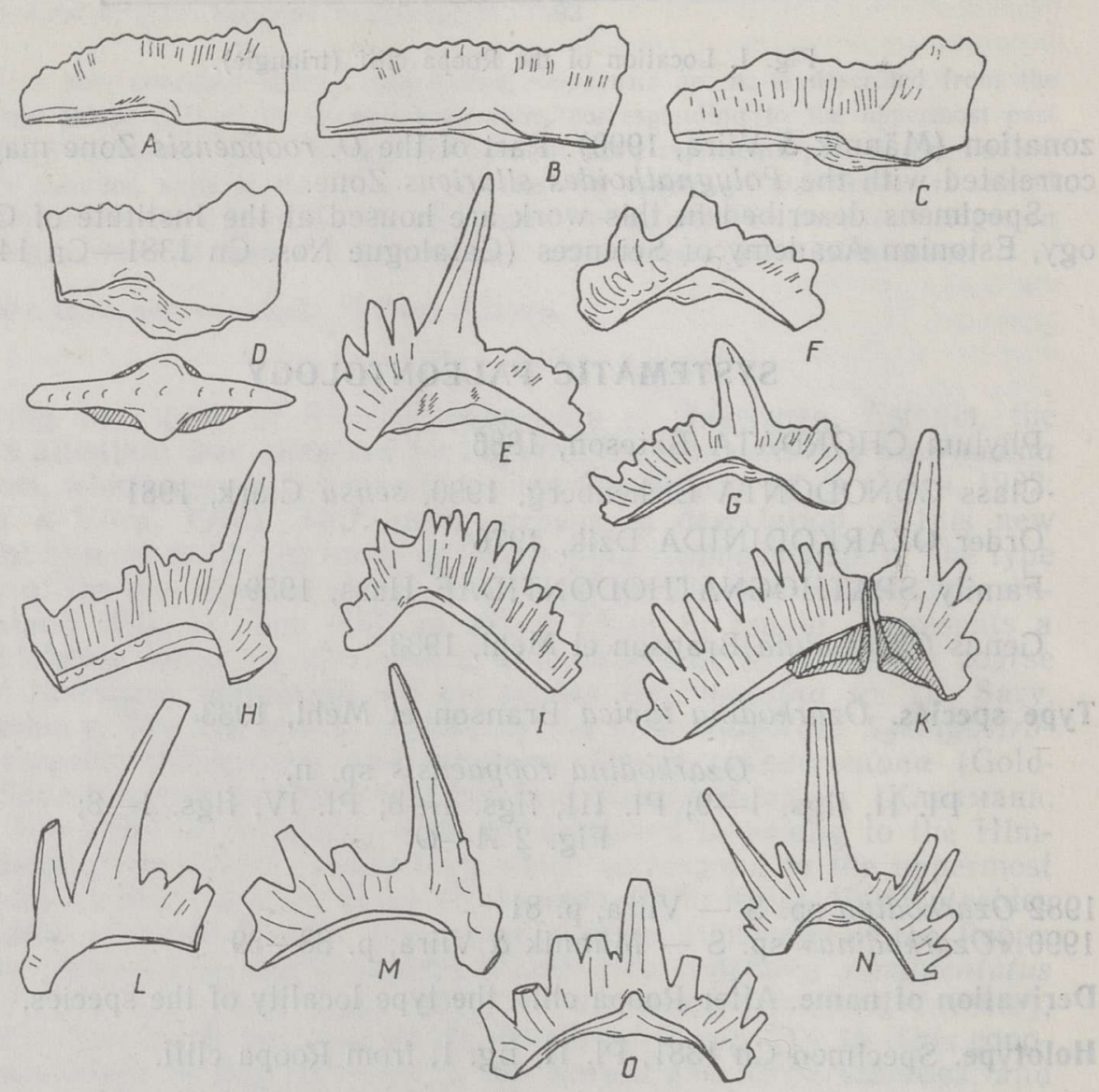

Fig. 2. Ozarkodina roopaensis sp. n. Vertical lines show the situation of white matter. $A, B, C, D-\mathrm{Pa}$ element $\mathrm{Cn} 1422-\mathrm{Cn} 1425 ; E, F, G-\mathrm{Pb}$ element $\mathrm{Cn} 1426-\mathrm{Cn}$ $1428 ; H, I, K-M$ element Cn 1429-Cn 1431; $L, M-$ Sc element Cn 1432, Cn 1433; $N$ - Sb element Cn 1434; $O$ - Sa element Cn 1435. Paadla Formation, $A, B, D, F-I$, $M-O$ - Roopa cliff; $C, E, K, L$ - Ohesaare boring, $115.85 \mathrm{~m}$. 
blade. The basal parts of the blade are slightly horizontally convex. The basal cavity is beneath the cusp and extends as grooves to the ends of the blade. There are areas of a recessive basal margin, especially in the posterior part of the blade.

The angulate $M$ element is synprioniodiniform. Characteristic is a long prominent posterior process directed posteriorly and downwards. The cusp is tall, erect, with sharp anterior and posterior edges. The posterior process bears numerous (up to 14), basally closely fused moderately high denticles. Anterior to the cusp the more downwardly directed process may bear up to five fused denticles. In some specimens, as seen in Pl. IV, fig. 6 , the anterior process is without denticles, or they may be simply broken. The inner lateral sides of the basal parts of the processes are slightly convex forming a horizontal minor rim. The basal cavity is beneath the cusp and extends as grooves to the ends of the anterior and posterior processes. The basal pit and its posterior extension have zones of a recessive basal margin.

The symmetry transition series elements $\mathrm{Sa}, \mathrm{Sb}$, and $\mathrm{Sc}$ have moderately low processes, a tall slender cusp, and rather high denticles. White matter is situated in the upper parts and around the roots of the denticles, almost reaching the basal margin. Quite a large part of the process proper has no white matter.

The Sc bipennate ramiform element has a high cusp and a rather short posterior process. Denticles are high and uneven. On the posterior process the biggest denticles are in the middle of or close to the posterior end; on the anterior process, however, near the cusp. There occur up to six denticles on the anterior process and some more on the pasterior process. The

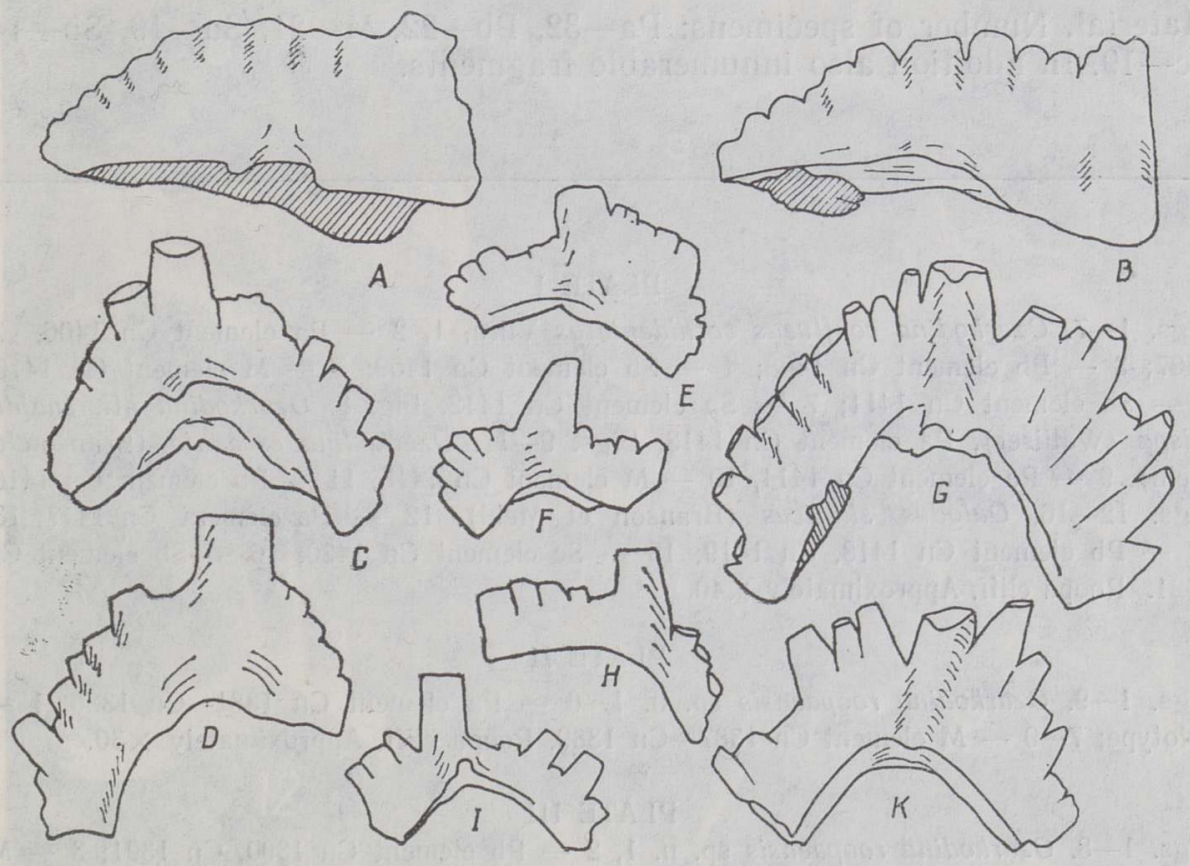

Fig. 3. Ozarkodina swetlanae (Mashkova).

$A$ - Pa element Cn 1202; $B-\mathrm{Pa}$ element Cn 1436; $C-M$ element Cn $1437 ; D-M$ element Cn 1220; $E, F-\mathrm{Pb}$ element Cn 1210, Cn 1438; $G$ - Sa element Cn 1238; $H$ - Sc element Cn 1213; I, K - Sb element Cn 1439, Cn 1236. Novaya Zemlya, Greben Stage; $A, C$ - Cape Fedotov 7919-12/2; B, G, K - Kuznetsov River 7950-8/6; D, E, F, H, I Kuznetsov River 7950-7/6. 
anterior process is bent downwards and to the inner side forming an almost right angle with the posterior process.

The $\mathrm{Sa}$ and $\mathrm{Sb}$ alate elements are very similar, though $\mathrm{Sa}$ is symmetri$\mathrm{cal}$ and $\mathrm{Sb}$ is unsymmetrical. The $\mathrm{Sb}$ element has one shorter process. The denticles located in the middle of this process are the biggest ones. Some specimens have denticles declined posteriorly. All symmetry transition series elements have basal cavities with the pit lying under the cusp. The grooves proceeding from this pit extend to the ends of processes. All elements have also narrow zones of a recessive basal margin.

Variation. All specimens are big, there is no variation in size. The presence of transverse ridges in the $\mathrm{Pa}$ element is irregular to some degree. The number of denticles on the anterior processes of the $M$ and Sc elements may also change.

Comparison. The new species differs from Ozarkodina confluens (Branson et Mehl) in its $\mathrm{Pa}$ element having primitive transverse ridges on oral smooth surfaces of denticles. Also the distribution of white matter is of a different type. Ozarkodina roopaensis sp. n. is very close to Ozarkodina swetlanae (Mashkova), the apparatus described from the Greben Stage of Novaya Zemlya (Вийра, 1981). The $\mathrm{Pa}$ element of $O$. roopaensis sp. $\mathrm{n}$. differs from that of $O$. swetlanae in having a longer blade and smaller thickness (Fig. 3). All elements of $O$. swetlanae are rather stout. The $M$ element of this species has usually more than five denticles on the anterior process.

Occurrence. Roopa and Karala outcrops, Ohesaare $111.10-115.85 \mathrm{~m}$, Riksu 30.3-36.0 m, Kolka $300.6 \mathrm{~m}$ borings.

Material. Number of specimens: $\mathrm{Pa}-32, \mathrm{~Pb}-22, \mathrm{M}-21, \mathrm{Sa}-19, \mathrm{Sb}-14$, $\mathrm{Sc}-19$. In addition also innumerable fragments.

\section{PLATE I}

Figs. 1-7. Ozarkodina confluens cornidentatus Viira. 1,2- Pa element $\mathrm{Cn}$ 1406, Cn 1407; 3 - Pb element $\mathrm{Cn} \mathrm{1408;} 4$ - Sb element $\mathrm{Cn} \mathrm{1409;5-M}$ element $\mathrm{Cn}$ 1410; 6 - Sc element Cn 1411; 7 - Sa element Cn 1412. Fig. 8. Ozarkodina aff. snajdri crispa (Walliser), $\mathrm{Pa}$ element $\mathrm{Cn}$ 1413. Figs. 9-11. Ozarkodina excavata (Branson et Mehl). 9 - Pa element $\mathrm{Cn}$ 1414, $10-\mathrm{M}$ element $\mathrm{Cn}$ 1415, 11 - Pb element $\mathrm{Cn} 1416$. Figs. 12-16. Oulodus siluricus (Branson et Mehl). 12 - Pa element Cn 1417; 13, 14 - Pb element $\mathrm{Cn} 1418$, Cn 1419; 15 - Sc element $\mathrm{Cn} 1420 ; 16$ - Sb element $\mathrm{Cn}$ 1421. Roopa cliff. Approximately $\times 40$.

\section{PLATE II}

Figs. 1-9. Ozarkodina roopaensis sp. n. 1-6 - Pa element Cn $1381-\mathrm{Cn} 1386,1-$ holotype; 7-9 - M element Cn 1387-Cn 1389. Roopa cliff. Approximately $\times 30$.

\section{PLATE III}

Figs. 1-8. Ozarkodina roopaensis sp. n. 1,2- Pb element $\mathrm{Cn} 1390$, Cn 1391; $3-\mathrm{M}$ element Cn 1392; 4, 5 - Sc element Cn 1393, Cn 1394; 6, 7 - Sa element Cn 1395, Cn 1396; 8 - Sb element Cn 1397. Roopa cliff. Approximately $\times 35$.

\section{PLATE IV}

Figs. 1-8. Ozarkodina roopaensis sp. n. $1-\mathrm{Pa}$ element $\mathrm{Cn} 1398 ; 2,3-\mathrm{Pb}$ element Cn 1399, Cn 1400; 4-6-M element Cn 1401-Cn 1403; 7 - Sb element Cn 1404; 8 Sc element Cn 1405. Karala outcrop. Approximately $\times 30$, 
PLATE I

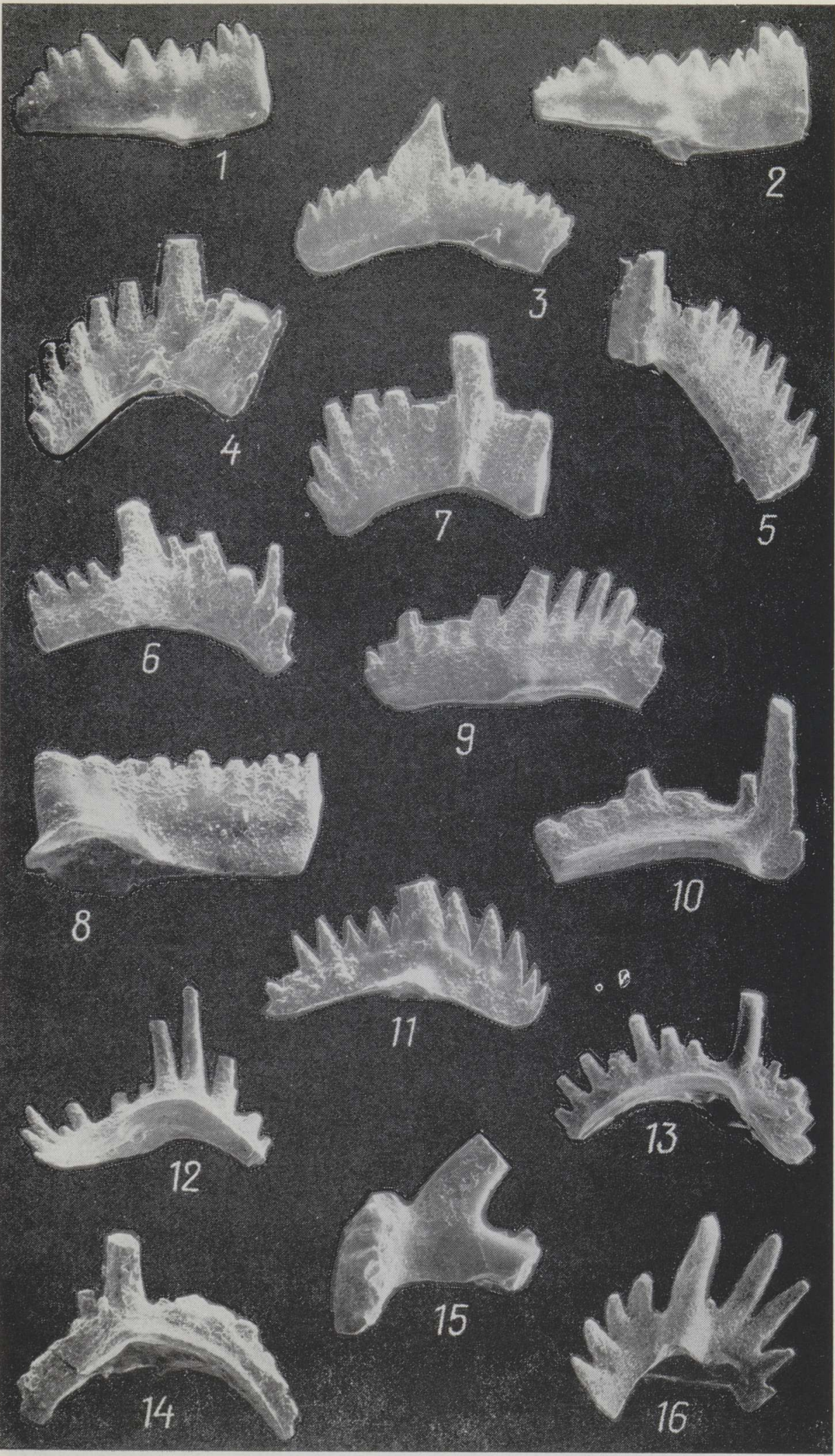




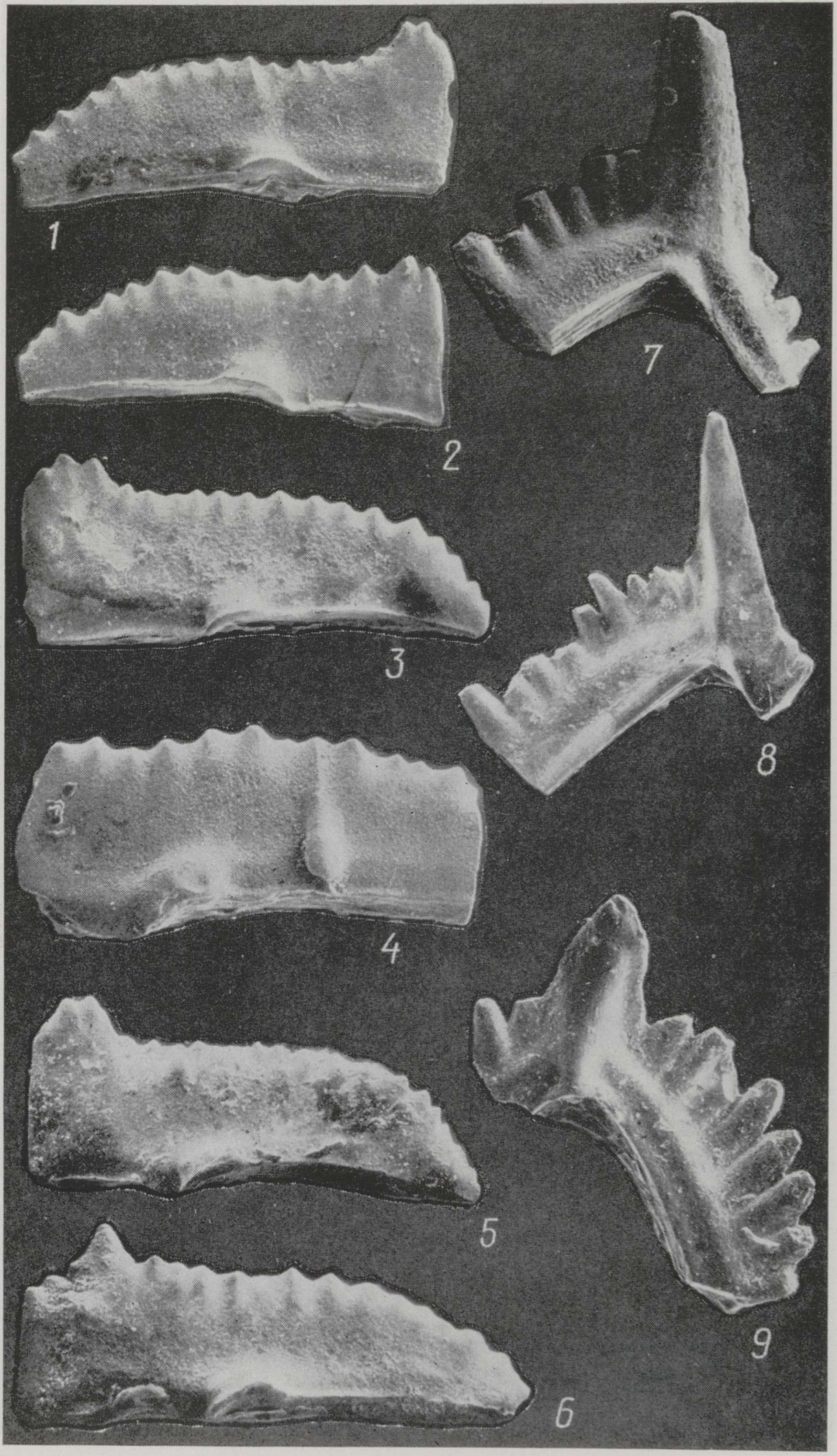


PLATE III

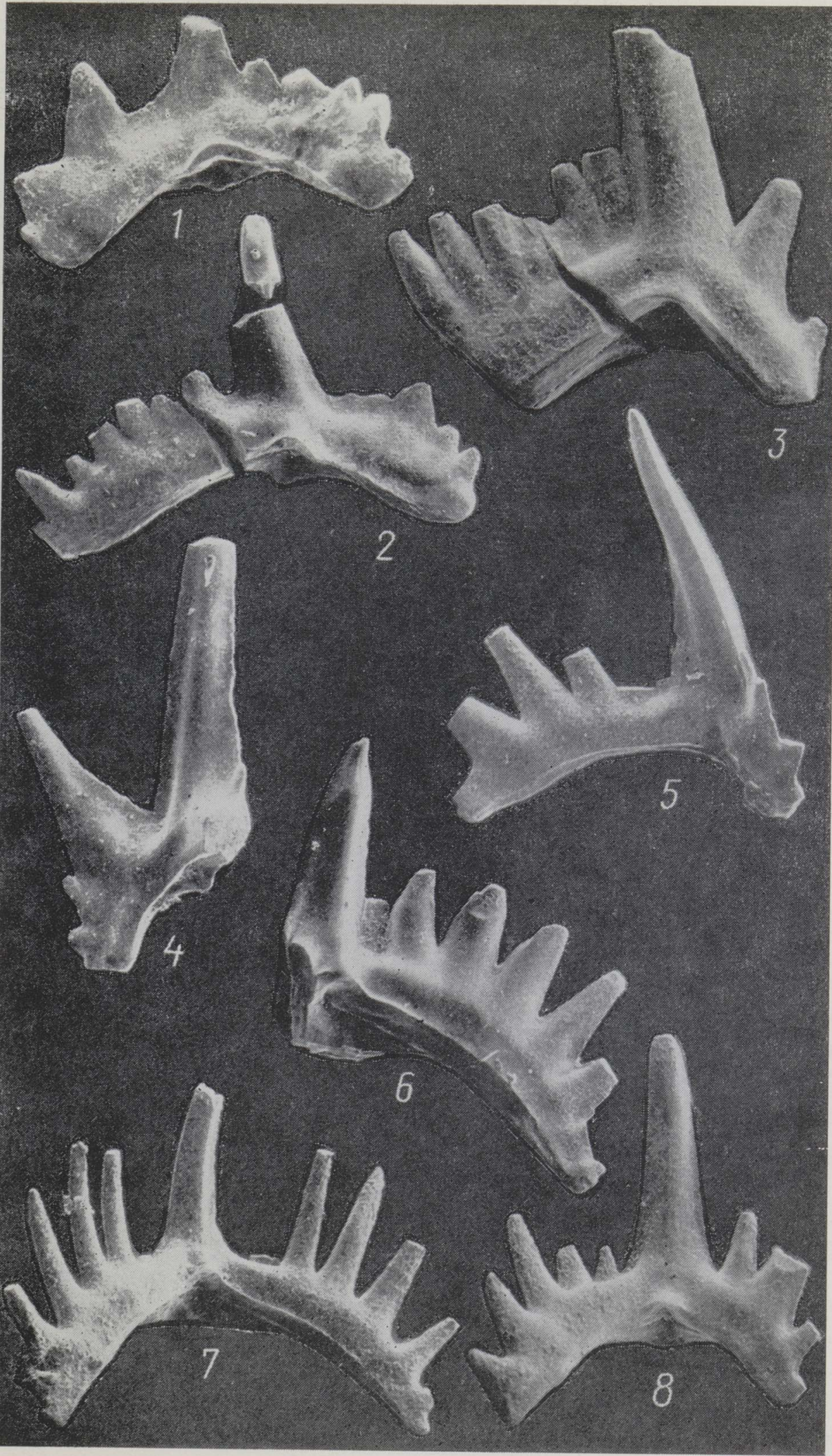




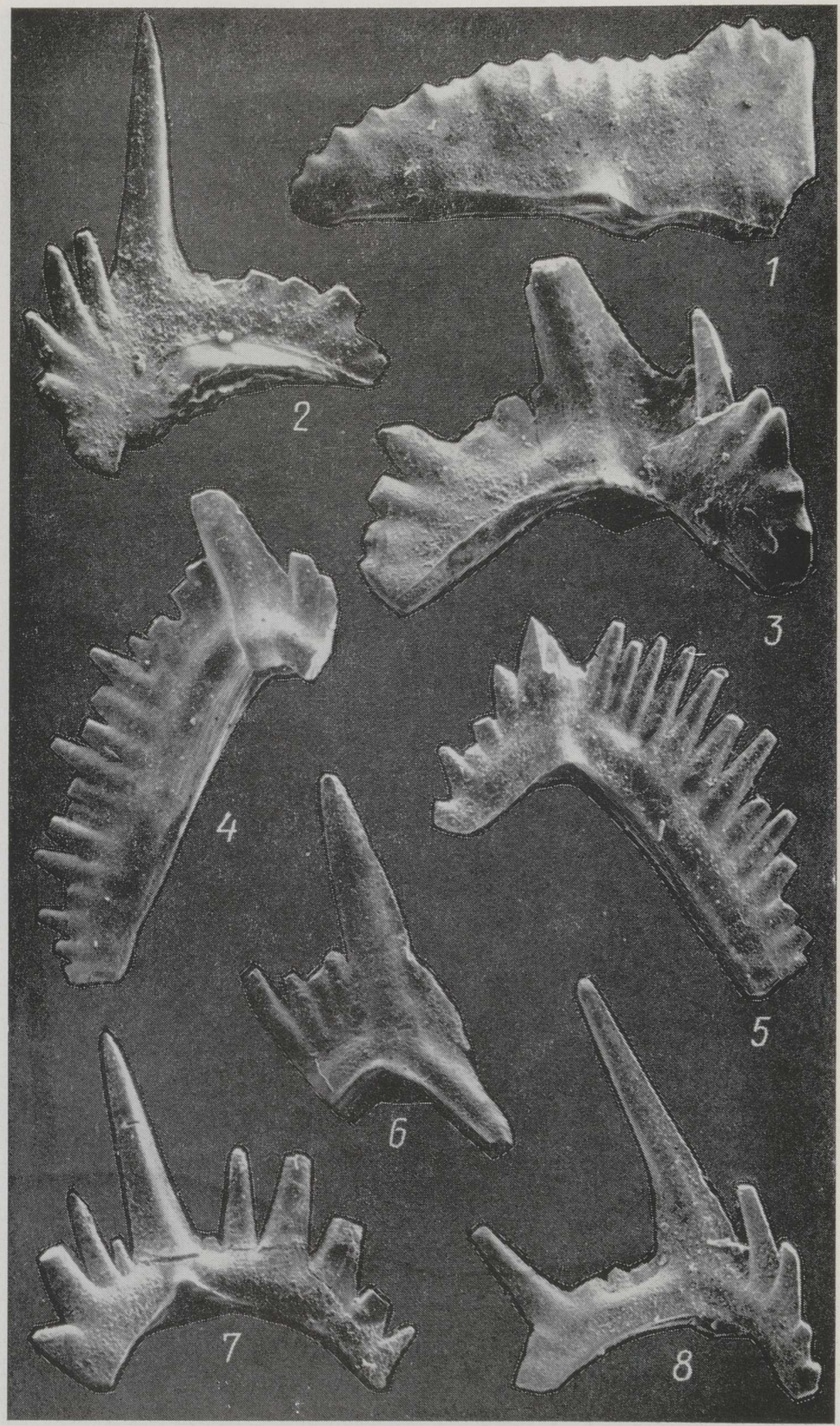




\section{ACKNOWLEDGEMENTS}

Thanks are expressed to Mrs. A. Noor, who kindly improved the language of the manuscript; to Mrs. K. Ronk, who drafted the illustrations, and to Miss U. Moldov for the SEM photos.

\section{REFERENCES}

Kaljo, D. 1990. The Silurian of Estonia. - In: Kaljo, D., Nestor, H. (eds.). Field Meeting Estonia 1990. An excursion guidebook. Tallinn, 21-26.

Männik, P., Viira, V. 1990. Conodonts. - In: Kaljo, D., Nestor, H. (eds.). Field Meeting Estonia 1990. An excursion guidebook. Tallinn, 84-89.

Viira, V. 1982. Late Silurian shallow and deep water conodonts of the East Baltic. In: Kaljo, D., Klaamann, E. (eds.). Ecostratigraphy of the East Baltic Silurian. Valgus, Tallinn, $79-87$.

Вийра В. Я. 1981. Конодонты. - In: Объяснительная записка к схеме стратиграфии верхнесилурийских отложений Вайгачско-Южноновоземельского региона. ВНИИОкеангеологин, Ленинград, 174-188.

Клааманн Э. 1970. Паадлаский горизонт. - In: Кальо Д. Л. (बd.). Силур Эстонии. Валгус, Таллинн, 276-286.

\section{UUS ULEMSILURI KONODONDILIIK EESTIST}

\section{Viive VIIRA}

On antud Paadla lademe kihtidest Lääne-Saaremaalt Roopa pangalt leitud uue konodondiliigi Ozarkodina roopaensis sp. n. kirjeldus. $O$. roopaensis'e tsoon on Baltikumi rannalähedase tsonaalsuse Ludlow'-ealine konodonditsoon.

\section{НОВЫЙ ВЕРХНЕСИЛУРИИСКИЙ КОНОДОНТОВЫЙ ВИД из Эстонии}

\section{Вийве ВИИРА}

Описан новый конодонтовый вид Ozarkodina roopaensis sp. n. из паадлаского горизонта, найденный в обнажении Роопа на западе о-ва Саapeмaа. Зона $O$. roopaensis является зоной лудловского возраста coгласно прибрежной зональной схеме Прибалтики. 